\title{
Turkish Validity and Reliability Study of Beliefs About Child TV Viewing Scale
}

\section{Çocuk Televizyon İzleme İnançları Ölçeği’nin Türkçe Geçerlilik ve Güvenilirlik Çalışması}

\author{
Güler Karakaya ${ }^{1}$, Funda Kardaş Özdemir ${ }^{2}$
}

\begin{abstract}
Objective: The aim of this study was to perform the validity and reliability study of the Turkish version of "The Beliefs about Child Television Viewing Scale". Methods: This methodological study included 266 parents with children aged 3-6 years old who were registered in 13 Family Health Centers, applied between the study dates, and met the inclusion criteria. Data was collected using the "Introductory Information Form" and "The Beliefs about Child Television Viewing Scale." The inventor of the scale, the ethics committee, the institutions, and the participants all gave their written consent. For the language validity of the scale, an expert opinion was requested, and a factor analysis was performed for construct validity. Results: According to the exploratory factor analysis, it was found that the scale had a four-factor structure and the factor values were in the reference range. According to the confirmatory factor analysis, it was found that the four-factor structure of the scale was valid and the fit indices were eligible. The Cronbach's $\alpha$ reliability coefficient was 0.85 and item-total score correlation coefficients were above 0.33. Conclusion: It was determined that the Turkish version of the Beliefs about Child Television Viewing Scale had acceptable validity and reliability results and could be used as a valid and reliable measurement tool.
\end{abstract}

Keywords: Child, beliefs, parent, validity, reliability, television.

\section{ÖZET}

Amaç: Bu çalışmanın amacı, "Çocuk Televizyon İzlemeye İlişkin İnançlar Ölçeği”nin Türkçe formunun geçerlik ve güvenirlik çalışmasını yapmaktır. Yöntem: Metodolojik tipte olan araştırmanın evrenini, 13 Aile Sağlı̆̆ı Merkezine kayıtlı, araştırmanın yapıldığı tarihler arasında sağlık merkezlerine başvuran ve araştırmaya dahil olma kriterlerini taşıyan 3-6 yaş çocuğu olan 266 ebeveyn oluşturmuştur. Veri toplamada, "Tanıtıcı Bilgi Formu” ve "Çocuk Televizyon İzleme İnançları Ölçeği” kullanılmıştır. Araştırmada ölçeği geliştiren yazardan, etik kuruldan, kurumdan ve katılımcılardan yazılı olarak izin alınmıştır. Ölçeğin dil geçerliliğinde uzman görüşlerinden faydalanılmış, yapı geçerliliğide ise faktör analizi uygulanmıştır. Bulgular: Açıklayıcı faktör analizine göre ölçeğin dört faktörlü bir yapı ortaya çıkardığı ve faktör değerlerinin uygun bir skalada bulunduğu, doğrulayıcı faktör analizine göre ise ölçeğin dört faktörlü yapısının geçerli olduğu ve uyum indekslerinin uygun olduğu bulunmuştur. Cronbach $\alpha$ güvenilirlik katsayısının 0.85 olduğu ve madde toplam puan korelasyon katsayılarının 0.33 'ün üzerinde bir değer aldığı tespit edilmiştir. Sonuç: Çocuk Televizyon İzleme İnançları Ölçeği' nin Türkçe formunun kabul edilebilir geçerlik-güvenilirlik sonuçlarına sahip olduğu, geçerli ve güvenilir bir ölçme aracı olarak faydalanılabileceği belirlenmiştir.

Anahtar Kelimeler: Çocuk, inançlar, ebeveyn, geçerlik, güvenilirlik, televizyon.

Received / Geliş tarihi: 29.07.2021, Accepted / Kabul tarihi: 04.10.2021

${ }^{1}$ Atatürk State Hospital, Zonguldak

${ }^{2}$ Kafkas University, Faculty of Health Sciences

*Address for Correspondence / Yazışma Adresi: Funda Kardaş Özdemir, Kafkas University, Faculty of Health Sciences, Kars / TURKEY, E-mail: fkardas@gmail.com

Karakaya G, Kardaş Özdemir F. Turkish Validity and Reliability Study of Beliefs About Child TV Viewing Scale. TJFMPC, 2021;15(4): 828-836.

DOI: $10.21763 /$ tjfmpc. 970623 


\section{INTRODUCTION}

Television, tablet computers, smart phones, and other forms of mass media currently play a vital role in both individual and social lives. People are exposed to messages from these tools at practically every instant of their lives, and they are exposed to messages from these tools throughout the day. ${ }^{1}$

Since the use of television is easy, it is a mass communication tool that is widely used and intended for all ages. Television can be utilized for a variety of reasons, including information gathering, entertainment, and education. People, on the other hand, unconsciously use television and other forms of mass media. ${ }^{2}$ Children watch too much television these days. Children who start watching television from an early age become more addicted in the future. ${ }^{3}$ If it is not used consciously, television has negative effects especially on children. The increasing spread of television means that children will be exposed to this situation even more. All necessary measures must be taken in order to protect children, who are in the developmental age and most vulnerable to external influences, from negative effects and to maintain their development in a positive way. ${ }^{1-4}$

Since children are watching television for the first time in a family setting, parents play a vital part in their children's developing a relationship with television. Parents can shape the knowledge and behaviors that children learn via television and contribute children to comprehend television and its nature in a health manner. ${ }^{5,6}$ Nowadays, some families see television as a caregiver and they allow their children to watch television instead of taking care of them. ${ }^{7}$

If the child watches television too much, problems may be experienced in the development of social activity, friend relations, school success and sportive activity skills. In accordance with the courses and school hours, children can be allowed to watch television in a controlled way by determining daily television hours. ${ }^{8}$ Parents can shape their children's television use habits and regulate television-watching time of their children and the content they watch. ${ }^{9}$

Despite the importance of the parents' effects on children's television watching, there are deficiencies in the literature regarding systematic measurement or psychometric evaluation in this field. There is no measurement tool in Turkey to measure the parents' beliefs about their children's television watching habits. The aim of this study was to perform Turkish validity and reliability study of the "Beliefs about Child TV Viewing Scale (B-TV)" developed by Thompson et al. (2018).

\section{METHODS}

Between May 2019 and January 2020, this methodological study was conducted in 13 Family Health Centers (FHCs) in Zonguldak province. The study's participants were parents of children aged 36 who were enrolled in these Family Health Centers. It has been suggested in the literature that for calculating sample size, 5-10 times the number of scale items should be used. 10 Because there are 22 scale items in this study, the sample size should be 110-220. The number of 3-6-year-old children registered at Family Health Centers in Zonguldak province's city center was estimated to be 5200. 290 parents with 3-6-year-old children who applied to the indicated Family Health Centers between the study dates were included in the study without employing the method of sample selection from the population. Since 24 parents refused to participate in the study, it was only finished with 266 parents.

\section{Data Collection}

Between the study days, parents who applied to the FHCs indicated and met the inclusion criteria were taken to a separate room, where the consent form was signed and data collection methods were used. Answering the data gathering tools took an average of 20-30 minutes. As data collection tools; "Descriptive Information Form" and "Beliefs about Child TV Viewing Scale (B-TV)" were used. Questions included in the Descriptive Information Form were prepared by the researchers in accordance with the literature..$^{2,9,11,12}$ They include 14 questions to determine the descriptive characteristics and TV watching habits of the children and parents.

Beliefs About Child TV Viewing Scale (B$\boldsymbol{T V})$ : It was developed by Thompson et al., in 2018 to evaluate the beliefs of parents of preschool children about TV viewing of children. ${ }^{9}$ The scale is composed of a total of 22 items. Each item of the scale is four-point Likert type ranging as " $1=$ Strongly disagree, 2=Disagree, 3=Agree, and $4=$ Strongly agree". Total scores of B-TV ranged between 22 and 88 . As a result of the factor analysis of the original scale, it was determined that the scale was composed of 4 subscales, Cronbach's $\alpha$ was 0.70 "positive general beliefs" subscale, 0.73 for "positive sleep related beliefs" subscale, 0.89 for "positive functional beliefs" subscale and 0.61 for "negative general beliefs" subscale and as a result, B-TV Scale was reported to be a valid and reliable scale. ${ }^{9}$

\section{Ethical Principles of the Study}

In order to adapt the scale to be used in the study to Turkish and conduct validity and reliability, 
permission was first obtained from Darcy A. Thompson, one of the authors who developed the original scale via e-mail on 25.01.2019. Ethics committee approval numbered as 81829502.903/59 indicating that the study was appropriate was obtained on 31.05.2019 from Kafkas University Faculty of Health Sciences. Institutional permission was obtained from Zonguldak Provincial Health Directorate associated with the FHCs in which the study was planned to be conducted. In order to protect the rights of parents with 3-6 year-old children included in the study, the "Informed Consent" form was filled by providing information first about the purpose, duration, and content of the study.

\section{Data Analysis}

The data were analyzed with SPSS for Windows 17 package program and LISREL 8.80 package program. In addition to the number, percentage, minimum and maximum values and mean and standard deviation in the analysis of data, Davis technique for content validity, KMO and Bartlett's coefficients for exploratory factor analysis, principal component analysis, Varimax rotation; in the confirmatory factor analysis, x2/SD value, GFI, AGFI, CFI, RMSEA, SRMR fit indices and PATH diagram were used. Internal consistency was determined with Cronbach's $\alpha$ coefficient, item total correlation and t-test.

\section{Language Validity}

In the Turkish adaptation of B-TV, internationally accepted steps of Mapi Research Institute were followed. ${ }^{13}$ First of all, permission was obtained from the developer of the scale for its Turkish adaptation. Two separate translations from English to Turkish were prepared by a linguist who knows English at an advanced level. After the obtained translations were reviewed by the researchers, a common translation text was prepared. The prepared translation text was translated back from Turkish to English again by a linguist. After making the necessary adjustments, 5 expert opinions were consulted to compare it with the original form of the scale and to question the English-Turkish cognitiveconceptual differences. Finally, the Turkish translation of the scale was checked by a Turkish language expert. After obtaining the language validity and content validity of the scale in line with the expert opinions, a preliminary application was made with 20 parents to evaluate the comprehensibility of the questions and no revision was found to be needed. Study forms applied to these people were excluded from the study.

\section{Content Validity}

In this study, opinions of an expert group consisting of 5 people were obtained. Davis Technique was benefited for content validity. The scale translated into Turkish was sent to experts and they were asked to evaluate each item as "not suitable" (1), "needs to be made suitable" (2), "suitable but needs minor revisions" (3), "very suitable" (4). ${ }^{14-16}$

\section{Generalizability of the Study}

The results obtained from the study can be generalized to parents of 3-6 year-old children living in the city center of Zonguldak province.

\section{RESULTS}

It was found that $55.3 \%$ of the children of the participants were boys, $85.7 \%$ of the participants were girls, $60.9 \%$ had high school or higher education degree, $95.9 \%$ were living with their spouses and $60.1 \%$ were unemployed. One of the family members was providing care to the children of $71.4 \%$ of the participants. The mean age of the participants was $34.75 \pm 5.50$ years, the mean age of children was $50.32 \pm 12.21$ months and the number of children at home was $1.92 \pm 0.73$. The average TV watching time for the children was $137.26 \pm 102.31$ minutes, mothers' average TV watching time was $129.62 \pm 107.88$ minutes, fathers' average TV watching time was $144.14 \pm 118.67$ minutes, and the total TV watching time at home was $337.78 \pm 197.03$ minutes (Table 1). 


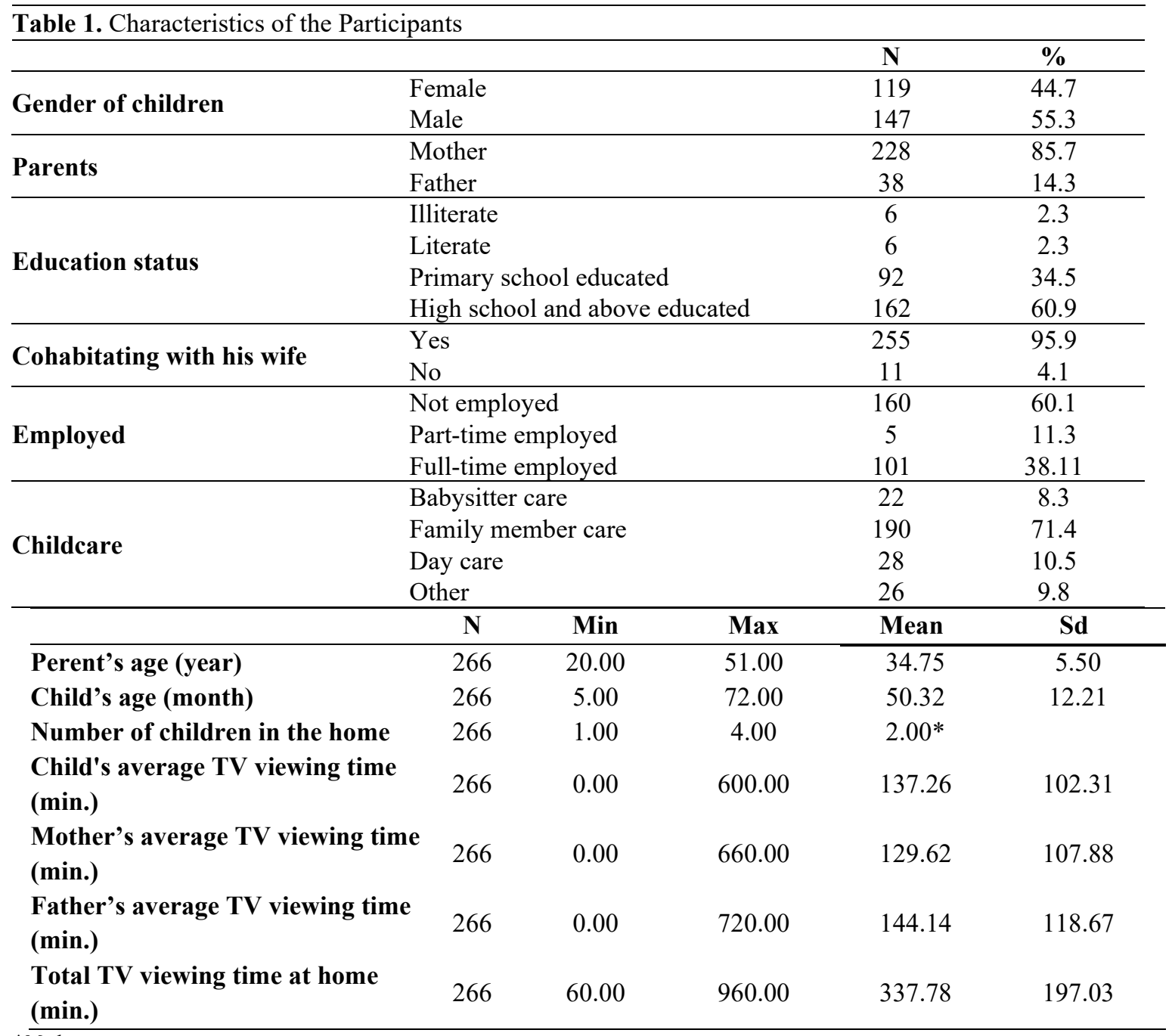

After the translation process of the scale was completed, opinions of five experts were consulted for an evaluation including cultural equivalence to ensure content validity. In accordance with the expert opinions, content validity was evaluated using Davis technique. KGİ scores of all items in the B-TV Scale were found to be 1.0 since all experts rated all items between 3-4 points. Therefore, no item was removed from the scale in terms of content validity.

After the content validity, factor analysis was performed to determine the construct validity. To evaluate sample adequacy and suitability of data for factor analysis before factor analysis, KaiserMeyer-Olkin (KMO) and Bartlett's tests were applied. KMO value was determined as 0.847 and this value indicates the suitability for principal components analysis. Similarly, Bartlett's test results $\left(x^{2}=3010.586, \mathrm{p}=0.000\right)$ also showed that the data were related to each other and were suitable for factor analysis.

As seen in Table 2, factor loadings of all items of the scale were above 0.40 and the variance explained was 10.710 for Positive General Beliefs subscale, 15.032 for Positive Sleep Related Beliefs subscale, 18.740 for Positive Functional Beliefs subscale, 13.904 for Negative General Beliefs subscale, and 58.386 for the total score of B-TV Scale. Therefore, no item was removed from the scale at this step and the structure with 4 subscales was accepted. The last two items of the scale were not placed under any factor, similar to the original scale. It was determined that the factor load of the $21^{\text {st }}$ question from these items was below 0.30 and the $22^{\text {nd }}$ question was loaded in two factors. 
Table 2. Factor Structure of the Beliefs about Child TV Viewing (B-TV) Scale.

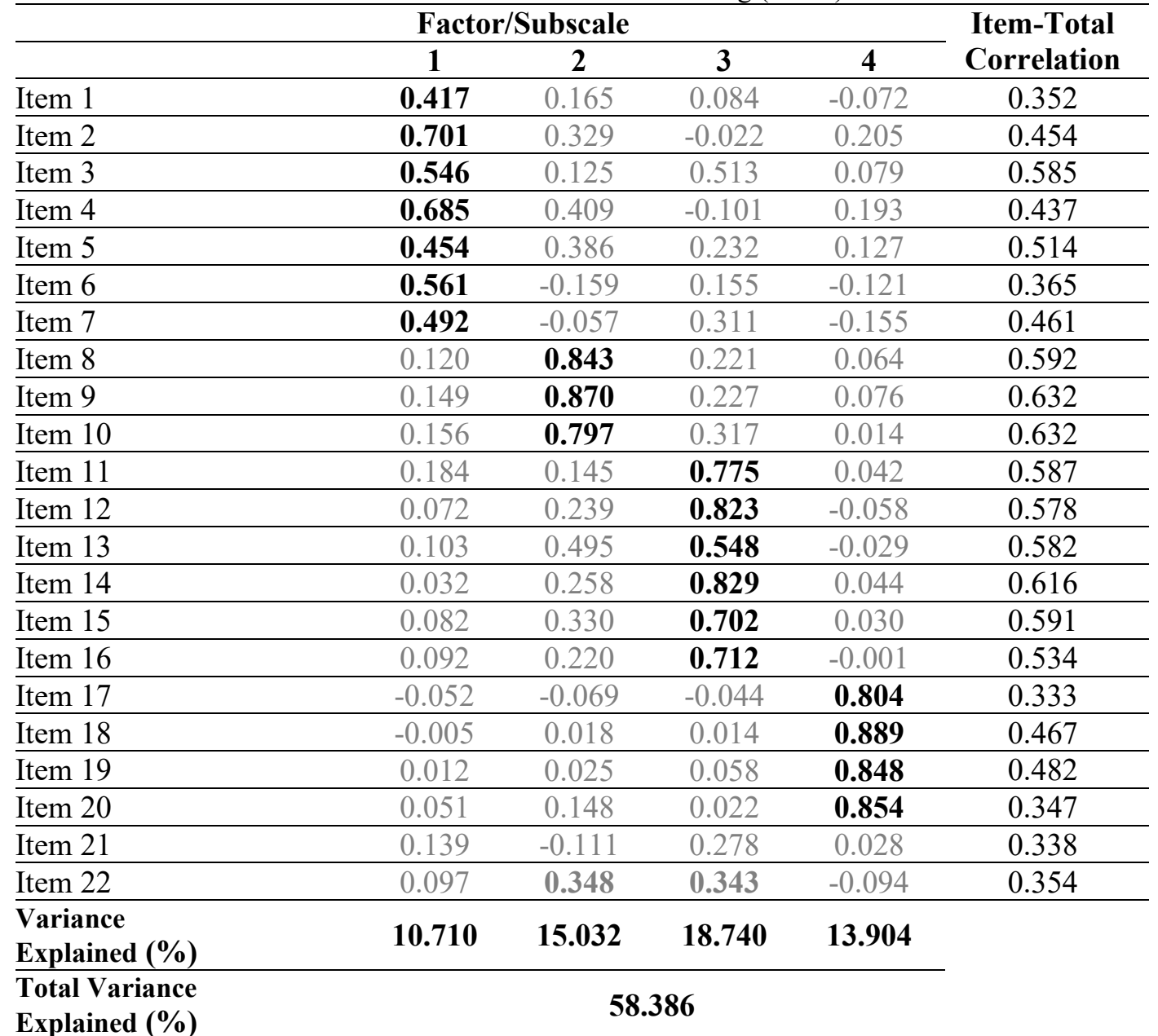

*Varimax Rotation, 1: "Positive General Beliefs", 2: "Positive Sleep- Related Beliefs", 3: "Positive Functional Beliefs", 4: "Negative General Beliefs"

Many indexes were benefited to investigate the fit of the model of the B-TV Scale. Among them, it was found that $x^{2} / \mathrm{SD}$ value was 2.90 , GFI was 0.94, AGFI was 0.90, CFI was 0.94, RMSEA was 0.79, and SRMR was 0.096. It was determined as a result of the related fit index values that the model was acceptable except for the SRMR fit index.

The total Cronbach's $\alpha$ coefficient was 0.855 for the B-TV Scale, 0.717 for Positive General Beliefs subscale, 0.918 for Positive Sleep Related Beliefs subscale, 0.889 for Positive Functional Beliefs subscale, and 0.877 for Negative General
Beliefs subscale. Item total correlation values for all items of the scale were positive and deleting of any item did not cause a significant increase in Cronbach's $\alpha$ coefficient. Therefore, at this stage, no item was excluded from the scale. As seen in Table 3 , the participants received $15.85 \pm 2.90$ points from the Positive General Beliefs subscale, 5.61 \pm 1.74 points from the Positive Sleep Related Beliefs subscale, $13.44 \pm 3.31$ points from the Positive Functional Beliefs subscale, and $8.83 \pm 2.66$ points from the Negative General Beliefs subscale. Total mean score obtained from the B-TV Scale was $48.40 \pm 7.68$.

Table 3. Distribution of Scores of the Beliefs about Child TV Viewing (B-TV) Scale and Subscales

\begin{tabular}{lccccc}
\hline & N & Min & Max & Mean & Sd \\
\hline Factor 1 & 266 & 7.00 & 27.00 & 15.85 & 2.90 \\
Factor 2 & 266 & 3.00 & 12.00 & 5.61 & 1.74 \\
Factor 3 & 266 & 6.00 & 24.00 & 13.44 & 3.31 \\
Factor 4 & 266 & 4.00 & 16.00 & 8.83 & 2.66 \\
\hline Total Score & $\mathbf{2 6 6}$ & $\mathbf{2 2 . 0 0}$ & $\mathbf{7 1 . 0 0}$ & $\mathbf{4 8 . 4 0}$ & $\mathbf{7 . 6 8}$ \\
\hline
\end{tabular}




\section{DISCUSSION}

The study was conducted to determine validity and reliability of the Turkish version of Beliefs about Child TV Viewing (B-TV) Scale developed in English by Thompson et al., in 2018 to measure beliefs of parents having 3-6 year-old children about child television viewing and it was found that the BTV Scale was a valid and reliable tool in Turkish.

Validity is the most crucial feature of a measurement tool. In reality, even if a measurement equipment is dependable, it may not always be accurate. As a result, ensuring validity in measurement instruments should be a top focus. ${ }^{17}$ Validity shows what and how accurately a measurement tool measures. ${ }^{18}$

In scale validity and reliability research, the language validity criterion is required to conduct language adaptation first. The selection of translation professionals and the translation procedure are the most crucial aspects of language adaptation. The translation experts should not only be fluent in both languages, but also in scale structures, know how to utilize the scale, and have the qualifications to assess the study's methodology. ${ }^{14,15}$ The Turkish language validity of the "Beliefs About Child TV Viewing Scale (BTV)" developed in English by Thompson et al., in 2018 was performed by translation-back translation method.

Content validity is the degree to which a measurement tool can cover the qualities to be measured, and it is done to evaluate whether the scale as a whole contains different concepts other than the concept to be measured. For content validity, opinions of experts related to the field are taken. ${ }^{17,19}$ After the translation process, Davis technique was used to evaluate the content validity. The number of experts counseled in this technique can be between 3 and 20. ${ }^{19}$ Opinions of five academicians who were experts in their fields were consulted for the content validity of the B-TV Scale. The Content Validity Index (CVI) determined in the study was 1.00 . In this context, the scale was sufficient in terms of content validity.

After the content validity, a preliminary application was performed to measure the comprehensibility of the questions. The preliminary application of the scale was performed with 20 parents who had 3-6 year-old children and had similar characteristics with the people constituting the sample group and it was determined as a result of this preliminary application that no change was necessary.
Construct validity evaluates how much the tool, used to measure a concept that is difficult to observe and measure directly, reaches its goal and how accurately it can measure the abstract concept to be measured. ${ }^{10}$ In this study, factor analysis was performed to evaluate the construct validity. Before examining the factor structure of the Beliefs about Child TV Viewing (B-TV) Scale, Kaiser-MeyerOlkin (KMO) test to assess if the sample is sufficient for factor analysis and Bartlett's test to evaluate if the variables are correlated with each other were performed $(10,20)$. Kaiser-Meyer-Olkin (KMO) values are evaluated as perfect if they are between $0.90-1.00$, very good between $0.80-0.89$, good between $0.70-0.79$, moderate between 0.60-0.69, and weak between $0.50-0.59$ and they are not accepted if they are below $0.50 .^{21}$

The KMO score in this study was 0.847 , indicating that the sample fit for main components analysis is very good. The scale is suitable for factor analysis if the result of Bartlett's test in scale adaptation is statistically significant. ${ }^{16}$ In this study, Bartlett's test value was found as $x 2=3010.586$, $\mathrm{p}<0.01$. Bartlett's test results also showed that the data were correlated with each other and were suitable for factor analysis.

"Factor Analysis" is used for scale having more than one subscale. The main purpose in factor analysis is to investigate if or not the scale items are collected under different dimensions and ensure the formation of new factors. ${ }^{20,22}$ As a result of the combination of items measuring the same factor, various groups are formed and each factor group is named according to the properties of the items included. Factor analysis is performed with 2 different methods including "Explanatory Factor Analysis (EFA)" and "Confirmatory Factor Analysis (CFA)". ${ }^{10}$

As a result of the Explanatory Factor Analysis performed in this study, it was determined that the factor structure of the scale was suitable for a four-subscale structure as in the original form. In this study, factor loads of all items were found to be above 0.40 and between $0.41-0.88$. They were between $0.36-0.89$ in the study of Thompson et al. ${ }^{9}$ As in the study of Thompson et al., factor analysis results showed that items between 1-7 were loaded on factor 1 , items between 8-10 were loaded on factor 2, items between 11-16 were loaded on factor 3 and items between 17-20 were loaded on factor 4 at a high level. It was determined that the factor load of the $21^{\text {st }}$ question from the scale items was below 0.30 and the $22^{\text {nd }}$ question was loaded on two factors. The last two items of the scale could not be included under any factor, similar to the original scale. 
An important criterion of factor analysis is that the explained variance exceeds $50 \%$ of the total variance..$^{23}$ In the study, the explained variance was determined as $58.386 \%$. In the study, the explanatory factor analysis results revealed that item factor loads and explained variance were in sufficient level.

In order for the construct validity of a scale to be appropriate, "Goodness of Fit Statistics" performed in confirmatory factor analysis should be at the intended level. ${ }^{24}$ In the literature, RMSEA and SRMR values close to $0.00, \mathrm{CFI}, \mathrm{GFI}$ and AGFI values close to 1.00 and the result obtained from $\mathrm{x}^{2} / \mathrm{SD}$ ratio of 3.00 and below are interpreted as a good fit of the scale. ${ }^{17,25}$ In the confirmatory factor analysis, in which the fit of items included under the factors prepared in the explanatory factor analysis was tested, it was seen that the fit indices of the model $(\mathrm{x} 2 / \mathrm{SD}=2.90, \quad \mathrm{RMSEA}=0.79, \quad \mathrm{GFI}=0.92$, $\mathrm{CFI}=0.94, \quad \mathrm{AGFI}=0.90, \quad \mathrm{SRMR}=0.096) \quad$ were sufficient except for the SRMR value and compatible with the explanatory factor analysis. In conclusion, the 4-factor structure of the B-TV Scale with 22 items was suitable for the model and met the construct validity of the scale as in the original scale. This result was interpreted as that the items adequately represented the determined subscale, were similar, were distributed similarly and it was a valid measurement tool for Turkey.

Item analysis provides the comparison of the variance of a scale item with the variance of the total score of the scale and the examination of the correlation between them. ${ }^{10}$ The literature takes 0.20 as the minimum level for the item-total score correlation coefficient and the item scores between $0.30-0.40$ refers to "good" level of distinction and above 0.40 refers to "very good" level of distinction. ${ }^{16,19,22}$ Item total score correlation values in this study vary between $0.33-0.63$. Since the item total score correlation of all items was at sufficient level, no item was removed from the scale.

In order to determine the internal consistency and homogeneity of the B-TV Scale, the "Cronbach's a reliability coefficient" was calculated. Cronbach's $\alpha$ coefficient shows whether or not the items constituting the scale have sufficient homogeneity. It is expressed that Cronbach's $\alpha$ coefficient between $0.00 \leq \alpha \leq 0.40$ indicates that the scale is not reliable; if it is $0.40 \leq \alpha \leq 0.60$, then the scale has low reliability; if it is $0.60 \leq \alpha \leq 0.80$, then the scale is quite reliable; and if it is $0.80 \leq \alpha \leq 1.00$, then the scale is highly reliable. ${ }^{20}$ In this study, Cronbach's $\alpha$ reliability coefficient was 0.855 for BTV, 0.71 for Positive General Beliefs subscale, 0.91 for Positive Sleep Related Beliefs subscale, 0.88 for Positive Functional Beliefs subscale and 0.87 for Negative General Beliefs subscale and the scale was found to be quite and highly reliable. In the original scale, it was found as 0.70 for "Positive General Beliefs subscale", 0.73 for "Positive Sleep Related Beliefs subscale", 0.89 for "Positive Functional Beliefs subscale", and 0.61 for "Negative General Beliefs subscale". 9 The results obtained from the study related to the Cronbach's $\alpha$ reliability coefficient of the scale were similar with the original scale study. In the light of this information, the "Beliefs about Child TV Viewing (B-TV) Scale" was found to be a scale with high internal consistency and homogeneity.

\section{CONCLUSION}

Consequently, it was determined that the "Beliefs about Child TV Viewing (B-TV)" Scale was a valid and reliable tool in Turkish. More extensive studies can be carried out using different samples for the BTV Scale found to be a valid and reliable measurement tool. The scale validity and reliability results can be compared with the obtained results and the differences can be investigated, if any.

The scale is recommended to be used in other interventional studies that will be conducted about the parental beliefs for the purpose of supporting to develop healthy television watching habits of children in Turkey. In addition, it is recommended to expand education, guidance and counseling services in order to develop responsibility, awareness and sensitivity in parents to reduce the negative effects of television on children.

\section{REFERENCES}

1. Arslan A. Bir Sosyolojik Olgu Olarak Televizyon. Uluslararası İnsan Bilimleri Dergisi. 2004; 1(1):1-17.

2. Altınkılıç Z. Televizyon İzlemenin 1-6 Yaş Çocuk Sağlığı Üzerindeki Etkilerine Yönelik Annelerin Tutum ve Davranışlarının Belirlenmesi. Atatürk Üniversitesi Sağlık Bilimleri Enstitüsü, Çocuk Sağlığı ve Hastalıkları Hemşireliği Anabilim Dalı, Yüksek Lisans Tezi, Erzurum, 1-5, 2014.

3. Büyükbaykal G. Televizyonun çocuklar üzerindeki etkileri. İstanbul Üniversitesi İletişim Fakültesi Dergisi. 2007; 28: 31-44.

4. Güner F. İlköğretim II. Kademe Öğrencilerinin Televizyon Dizilerindeki Mesajları Algılamalarında Medya Okuryazarlığının Etkisi. On sekiz Mart Üniversitesi Sosyal Bilimler Enstitüsü, İlköğretim Anabilim Dalı. Yüksek Lisans tezi, Çanakkale, 1-58, 2011.

5. Lemish D. Children and Television, A Global Perspective. Oxford: Blackwell Publishing, 257 pp, 2007.

6. Ülken FB. Televizyon İzlemede Anne-Baba Aracılığı ile Çocukların Saldırgan Davranışları 
Arasındaki İlişki. Anadolu Üniversitesi Sosyal Bilimler Dergisi. 2011; 11(1): 195-216.

7. İçin Akçalı S. Çocuk ve Medya. Ankara: Nobel Akademik Yayınc1lık, 13-51, 2015.

8. Tümkan F. Televizyondaki Şiddetin Çocuk Üzerindeki Etkisi. KKTC Milli Eğitim Dergisi. 2007; 1: 67-88.

9. Thompson DA, Johnson SL, Schmiege SJ, Vandewater EA, Boles RE, Lev J, Tschann JM. Beliefs About Child TV Viewing in LowIncome Mexican American Parents of Preschoolers: Development of the Beliefs About Child TV Viewing Scale (B-TV). Maternal and Child Health Journal, 2018; 22(6):849-857.

10. Erdoğan S, Nahcıvan N, Esin N. Hemşirelikte Araştırma: Süreç, Uygulama ve Kritik. Nobel Tıp Kitabevi, İstanbul. s. 56-189, 2014.

11. Bekar P. Televizyon İzleme Durumunun Çocukların Kaygı Düzeyi ve Şiddete Eğilimine Etkisi. Atatürk Üniversitesi Sağlık Bilimleri Enstitüsü. Çocuk Sağlığı ve Hastalıkları Hemşireliği Anabilim Dalı. Yüksek Lisans Tezi, Erzurum, 30-46, 2014.

12. Serbest, SE. Spiritüel İyilik Ölçeği'nin Türkçe Geçerlilik Güvenilirlik Çalışması, Kafkas Üniversitesi Sağlık Bilimleri Enstitüsü Yüksek Lisans Tezi, Kars, 21-45, 2018.

13. Bayık A. Hemşirelik Araştırmalarında Etik. In: Hemşirelikte Araştırma, İlke, Süreç ve Yöntemleri, Eds: Erefe İ, 4. Bask1, Ankara, Hemşirelikte Araştırma ve Geliştirme DerneğiHEMAR-GE, Yayın No:1, 27-47, 2012.

14. Gözüm S, Aksayan S. Kültürlerarası ölçek uyarlaması için rehber: Ölçek uyarlama aşamaları ve dil uyarlaması. Hemşirelik Araştırma Dergisi. 2002; 4 (1): 914.

15. Erefe İ. Veri toplama araçlarının niteliği, In: Hemşirelikte Araştırma, İlke, Süreç ve
Yöntemleri, Eds: Erefe İ, 4. Bask1, Ankara, Hemşirelikte Araştırma ve Geliştirme DerneğiHEMAR-GE, Yayın No:1, 169-188, 2012.

16. Tavşancıl E. Tutumların Ölçülmesi ve SPSS İle Veri Analizi. 2. Baskı. Ankara, Nobel Yayın Dağıtım, 110-116, 2002.

17. Seçer İ. SPSS ve Lisrel ile pratik veri analizi, analiz ve raporlaştırma. 1.Baskı, Ankara, Anı Yayıncılık, s.171-81, 2013.

18. Esin MN. Veri toplama yöntem ve araçları, Veri toplama araçlarının güvenirlik ve geçerliği, In: Hemşirelikte Araştırma, süreç, uygulama ve kritik. Eds: Erdoğan S, Nahcivan N, Esin MN, İstanbul, Nobel Tip Kitabevleri, s.223-33, 2014.

19. Karasar N. Bilimsel Araştırma Yöntemi. 20. Baskı. Ankara, Nobel Yayın Dağıtım, 147-153, 2009.

20. Özdamar K. Paket Programlar İle İstatistiksel Veri Analizi. 5.Baskı. Eskişehir, Kaan Kitabevi, 450-455, 2004.

21. Büyüköztürk Ş. Veri Analizi El Kitabı. 8. Bask1. Ankara, Pegem Akademik Yayıncılık, 167-182, 2007.

22. Gözüm S, Aksayan S. Kültürlerarası ölçek uyarlaması için rehber II: Psikometrik özellikler ve kültürlerarası karşılaştırma. Hemşirelikte Araştırma Geliştirme Dergisi. 2003; 5: 3-14.

23. Yaşlıoğlu M. Sosyal Bilimlerde Faktör Analizi ve Geçerlilik: Keşfedici ve Doğrulayıcı Faktör Analizlerinin Kullanılmasi, İstanbul Üniversitesi İşletme Fakültesi Dergisi. 2017; 46:77.

24. Şimşek Ö. Yapısal Eşitlik Modellemesine Giriş. 1. Baskı. Ekinoks Basın Yayın, Ankara, 14-15, 2007.

25. Çapık C. Geçerlilik ve güvenilirlik çalışmalarında doğrulayıcı faktör analizinin kullanımı. Anadolu Hemşirelik ve Sağlık Bilimleri Dergisi. 2014; 17(3): 196-205.

\section{Çocuk Televizyon İzleme İnançları Ölçeği (İ-TV)}

\begin{tabular}{|l|l|l|l|}
\hline & & & \\
& & & \\
\hline 1.Okul öncesi çocuklar, televizyon izlerken önemli şeyler öğrenir & & & \\
\hline 2. Televizyon reklamları çoğunlukla çocuklar için sağlılı yiyecekleri gösterir & & & \\
\hline $\begin{array}{l}\text { 3. Televizyon reklamları çoğunlukla okul öncesi çocuğunuzun tüketmesini } \\
\text { istediğiniz yiyecek ve içecekleri gösterir }\end{array}$ & & & \\
\hline 4. Televizyon izlemek aile olarak beraber olmanın iyi bir yoludur & & & \\
\hline 5. Televizyon izlemek, okul öncesi çocukların sakinleşmesine yardımcı olabilir & & & \\
\hline 6. Okul öncesi çocuklar, televizyon izleyerek İngilizce öğrenirler & & & \\
\hline 7. Okul öncesi çocuklar, televizyon izleyerek eğlenirler & & & \\
\hline $\begin{array}{l}\text { 8. Çocuğunuzu (çocuğun adı) uyutmanın en iyi yollarından biri, ona (çocuğun } \\
\text { adi) televizyon izletmektir }\end{array}$ & & & \\
\hline
\end{tabular}




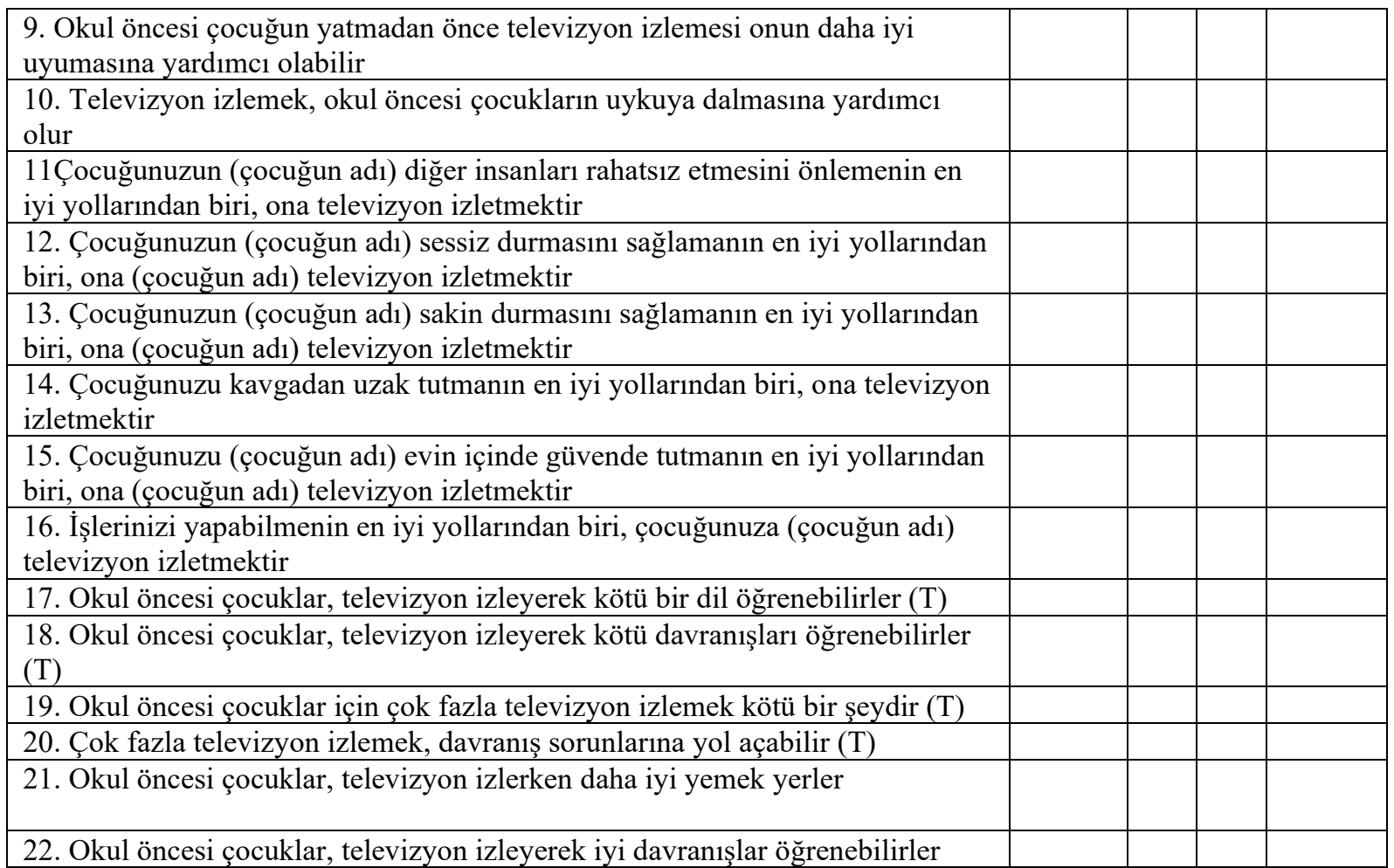

\section{$\mathrm{T}=$ Ters Kodlama}

